\title{
Behaviour of Structural Shear Wall with Recycled Aggregate Concrete using Sap2000
}

\author{
R. Chitra, Shruthi, M V, Rinu Isah
}

\begin{abstract}
Focus of the paper is to explore the behavioural characteristics of recycled aggregate concrete shear wall using SAP2000. In India, earthquakes are becoming threats to the human being and sequentially construction waste has been increasing due to the fast development of construction industries. According to a survey, 7 to 8 million tons of concrete demolition wastes are produced in India. This study focuses on the potential use of recycled waste aggregate in development of reinforced concrete shear wall. The appropriateness of result is constrained by the kind of divider and parameter subspace. Various disappointment modes can happen contingent upon parameter, for example, a sort of cross-segment, support itemizing and amounts, properties of strengthening steel, concrete compressive quality and limit condition. Complex ruinous wonders incorporate solid splitting, cooperation impact among steel and solid, steel yielding and solid squashing in pressure under non-straight powerful investigation. At long last, the reused total solid shear divider can continue the seismic plan necessity of a structure.
\end{abstract}

Keyword: SAP2000, recycled aggregate concrete (RAC), seismic analysis, non-linear dynamic analysis.

\section{INTRODUCTION}

Today, seismologist in many countries of the world is on the lookout for reliable techniques that would enable them to forecast the location, time and strength of earthquake. With such techniques put in our possession, explosive or fire hazardous processes and to evacuate people from building. Besides, to keep people under canvas for long time is acceptable in warm climate only. The earthquake hazard was neglected at the time of construction and damage to non-earthquake resistant structure was total. The exercise instructed from the harms because of seismic tremor and the examination work being done in the research facilities give better comprehension about the structure and their parts.

Revised Manuscript Received on October 22, 2019.

R. Chitra, Asistant Professor, Department Of Civil Engineering,,Bharath Institution of Higher Education And Research,TamilNadu, India Email: chitraroopauma@gmail.com

Shruthi M V, Asistant Professor,,Department Of Civil Engineering,,Bharath Institution Of Higher Education And Research,TamilNadu, India .Email: shruthigokulkrishnan@gmail.com

Rinu Isah, Asistant Professor,,Department Of Civil Engineering,,Bharath Institution Of Higher Education And Research,TamilNadu, India .Email: rinuisah@gmail.com@gmail.com
Harm in reused total solid structure was mostly respected to the deficient specifying of support, absence of vertical steel and repression of cement in basic component. Run of the mill disappointment was weak in nature, exhibiting lacking ability to disperse and retain inelastic vitality. This requires a superior comprehension of the plan and specifying of fortified solid structure under different stacking. To carry out these process, the SAP2000 extends the capabilities by adding a nonlinear element, a multilinear plastic hinge for use in frame element, cable behavior, geometric effect, including pushover analysis , non linear time history analysis by modal superposition or direct integration buckling analysis ; and frequency domain - analysis.

\section{REVIEW OF LITERATURE}

Norio et al (1997) introduced a paper on numerical method for dynamic non-direct limited component examination is proposed to break down 3-D strengthened solid shear divider structure exposed to seismic tremor movement. The demonstrated shear divider is semi 3-D structure which is made out of plane component considering the in-plane solidness of symmetrical rib boards. The test outcomes are performed one of the dynamic model test for assessment of seismic conduct of atomic reactor building. Qiuhongzhao (2004) researched on composite shear divider framework which is utilized as horizontal opposing framework in elevated structure the example had the option to withstand 33 cycle of example removal and it arrives at the most extreme bury story float more than 0.05 . The outline of this exploration is during plate cycle and after shear yielding of the steel plate, inelastic nearby clasping of the steel plate and inelastic neighborhood clasping of the steel plate shear divider happened in territory between the jolts. Suchitatuppad (2005) displayed a paper on use of programming for ideal situating of fortified solid shear divider in a multi story structure exposed to seismic conduct. The primary point of this work is to limit the parallel uprooting of the multi story working with shear divider exposed to seismic tremor load.

\section{A. Goal of study The most important objective of present} study includes:
Engineering \& Sciences Publication 
- To identify the behavioural characteristic of RAC shear wall during a seismic loading using non-linear dynamic analysis.

- To understand the effectiveness of Recycled Aggregate Concrete during a seismic behaviour.

\section{EXPERIMENTAL STUDY ON RAC}

The aim of the paper is to compare the basic properties of natural aggregate concrete (NAC) and the properties of $25 \%$ recycled aggregate concrete $(\mathrm{RAC})$. Coarse aggregate are the most mined material in the world. Coarse aggregate are a component of composite material such as concrete and asphalt concrete; the aggregate serves as reinforcement to add strength to the overall composite material. Gravel of size $12 \mathrm{~mm}$ is sieved and used in this research. Table -1 and Table -2 shows the physical properties and mechanical properties of both RAC and NAC (natural aggregate concrete) respectively was determined as per IS2386(1963) part-1.[1]-[6]

Table -1 Physical Properties of NAC and RAC

\begin{tabular}{|c|c|c|}
\hline Coarse aggregate & Natural & Recycled \\
\hline $\begin{array}{c}10 \mathrm{~min} \text { water } \\
\text { absorption }(\%)\end{array}$ & 0.6 & 2.6 \\
\hline Impact value (\%) & 15.9 & 22 \\
\hline Specific gravity & 2.68 & 2.59 \\
\hline $\begin{array}{c}\text { Bulk density } \\
\left(\mathrm{Kg} / \mathrm{m}^{3}\right)\end{array}$ & 1600 & 1439 \\
\hline Abrasion value (\%) & 27.6 & 44.6 \\
\hline Crushing value ( $\%)$ & 11.3 & 24.33 \\
\hline Flakiness index (\%) & 24.5 & 5.4 \\
\hline
\end{tabular}

Table - 2 Mechanical Properties of NAC and RAC

\begin{tabular}{|l|l|l|l|}
\hline Specimen & $\begin{array}{l}\text { Compressive } \\
\text { strength of } \\
\text { cube (MPa) }\end{array}$ & $\begin{array}{l}\text { Axial } \\
\text { compressive } \\
\text { strength } \\
(\mathrm{MPa})\end{array}$ & $\begin{array}{l}\text { Elastic } \\
\text { modulus } \\
\text { X104 } \\
(\mathrm{MPa})\end{array}$ \\
\hline $\begin{array}{l}\text { Conventional } \\
\text { concrete }\end{array}$ & 28.73 & 21.00 & 1.92 \\
\hline $\begin{array}{l}\text { Recycled } \\
\text { aggregate } \\
\text { concrete } \\
\text { with 25\% } \\
\text { replacement }\end{array}$ & 26.62 & 17.15 & 1.77 \\
\hline
\end{tabular}

\section{MODELLING AND ANALYSIS}

The current work includes the comparative study of RAC and NAC six storey shear wall in zone IV is analyzed using SAP 2000. Seismic analysis is done using equivalent lateral force method.
For this work, G+5 storey building with $3 \mathrm{~m}$ height for every storey is taken. Building has four bays of $5 \mathrm{~m}$ width in both $\mathrm{X}$ and $\mathrm{Y}$ direction building material properties are given below. In this work, the behavior of RAC structure and NAC structure is taken as objective function. The objective function of the work is to know the effectiveness of RAC during a seismic behavior

The input for genetic algorithm are programmed as,

- In -plane element component behavior is non-linear

- Out of plane element component behavior is linear

- Stiffness reduced to $75 \%$ to exclude the effect of cracking

- Provide $3 \%$ confined element for boundary element at bottom of the floors

- Provide $0.4 \%$ unconfined element for in-between boundary element at the bottom floors

- Provide $0.3 \%$ of unconfined element for top floor / remaining floors

- Non-linear direct integration history has scale factor of 32.2. [7]-[12]

\section{BUILDING DESCRIPTION}

\begin{tabular}{|c|c|}
\hline Particulars & Data \\
\hline $\begin{array}{l}\text { Young's modulus of } \\
\mathrm{M}_{20} \text { NAC concrete, E }\end{array}$ & $1.92 \mathrm{~N} / \mathrm{mm}^{2}$ \\
\hline $\begin{array}{l}\text { Young's modulus of } \\
\mathrm{M}_{20} \mathrm{RAC} \text { concrete, } \mathrm{E}_{1}\end{array}$ & $1.77 \mathrm{~N} / \mathrm{mm}^{2}$ \\
\hline Steel Grade & $\mathrm{Fe}_{415}$ \\
\hline Density of RC & $25 \mathrm{~N} / \mathrm{mm}^{2}$ \\
\hline Number of storey & $\mathrm{G}+5$ \\
\hline Size of Beam & $0.20 \mathrm{~m} \mathrm{x} 0.20 \mathrm{~m}$ \\
\hline Size of Column & $0.20 \mathrm{~m} \mathrm{x} 0.20 \mathrm{~m}$ \\
\hline $\begin{array}{l}\text { Thickness of Shear } \\
\text { Wall }\end{array}$ & $0.4 \mathrm{~m}$ \\
\hline Height of all storey & $3 \mathrm{~m}$ \\
\hline Seismicity Zone & IV \\
\hline Soil type & III \\
\hline Importance factor (I) & 1 \\
\hline $\begin{array}{ll}\text { Response } & \text { reduction } \\
\text { factor }(R) & \end{array}$ & 5 \\
\hline
\end{tabular}

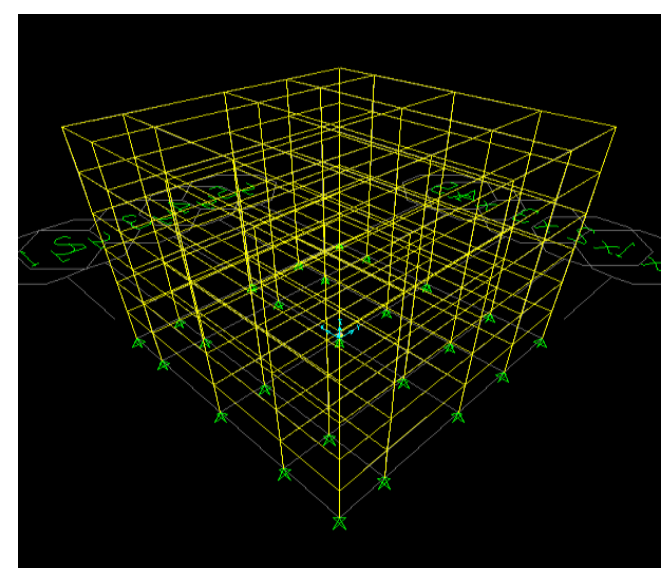

Fig1: framed structure to be analyzed 


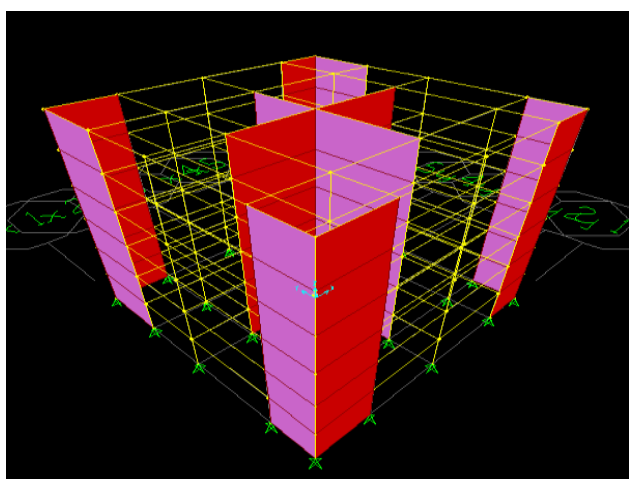

Fig2: location of shear wall for framed structure

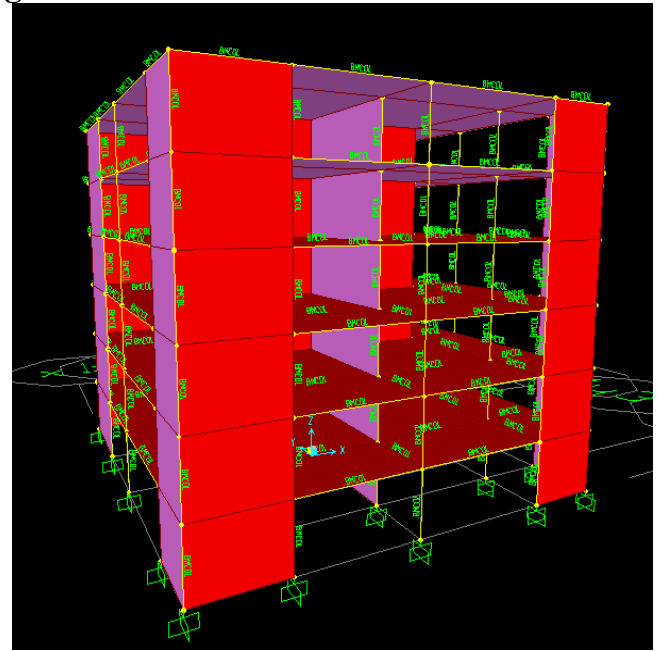

Fig3: framed building with material data inputted.

\section{RESUlT}

\section{A. Deformed shape for framed building}

The representation of the maximum response of idealized SDOF system having certain period and damping. The fig.a and fig.b. represent the deformed shape of shear wall building which contains RAC and NAC material respectively. From, the figure it's found that the response spectrum of NAC building shows 196 range with scale factor of 32.2. Whereas RAC building shows 350 range with the same scale factor[13]-[21]

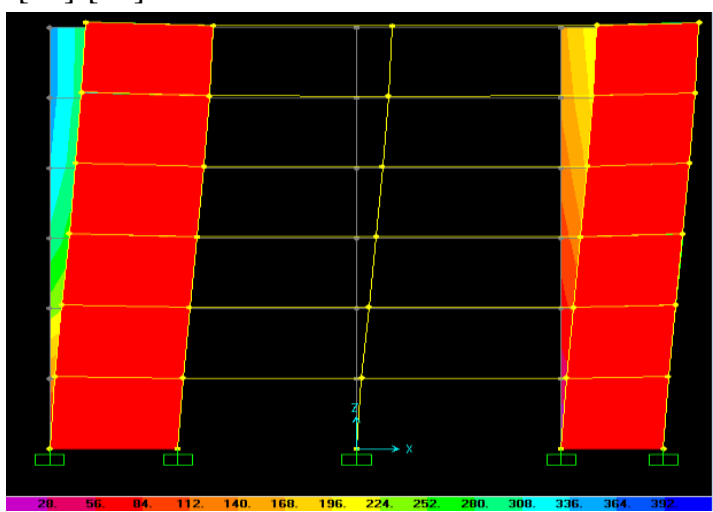

Fig4. deformed shape of building with NAC

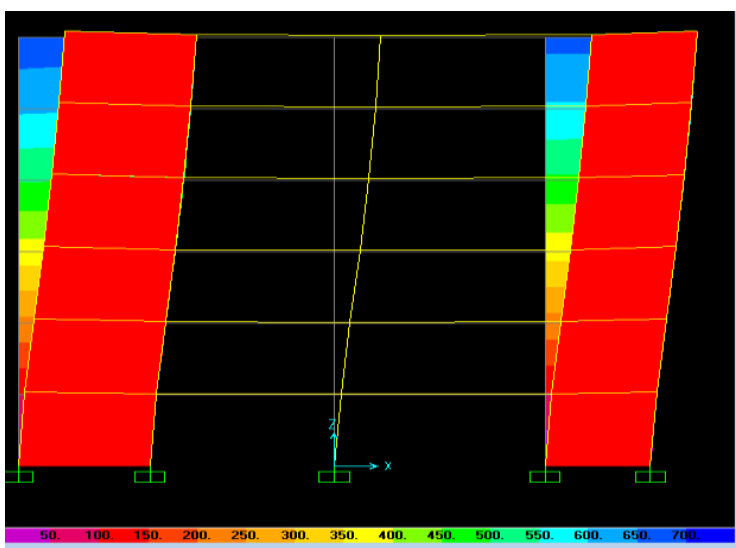

Fig 5. deformed shape of building with RAC

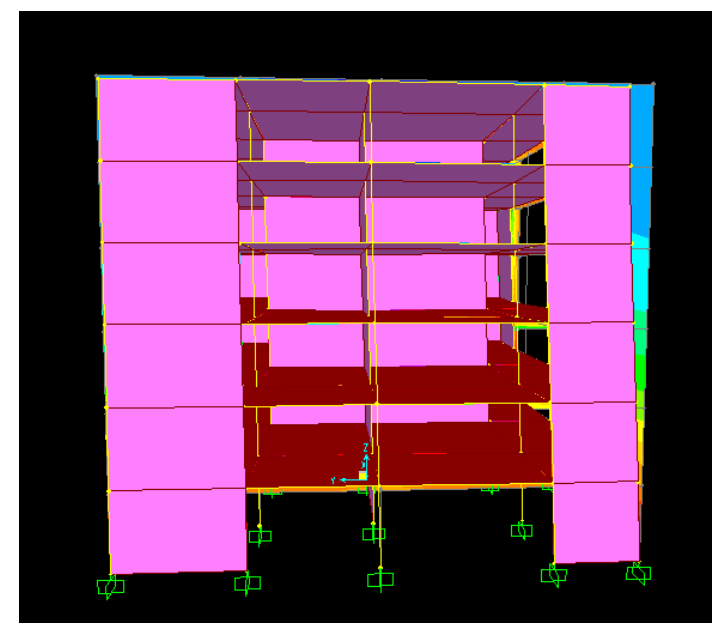

Fig .6. deformed shape of building with NAC-uplift force acting on it.

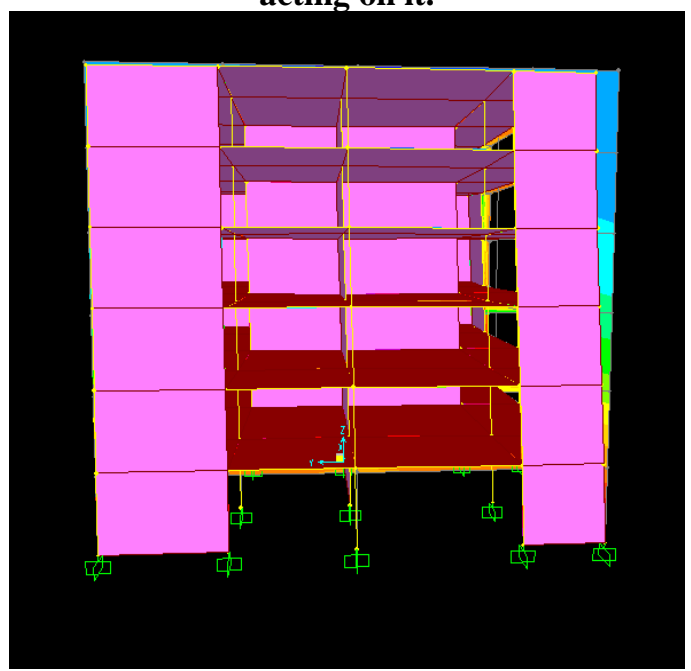

Fig.7. deformed shape of building with RAC-uplift force acting on it

B. Model mass for framed building

Fig.e and fig.f. Represent modal mass vibration of NAC and RAC framed shear wall

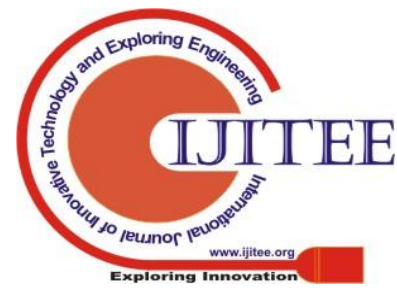




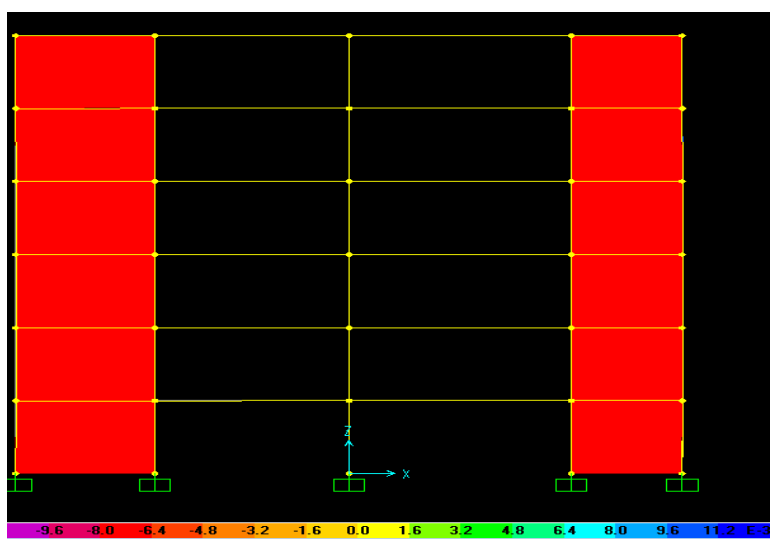

Fig.8. modal mass representation of NAC

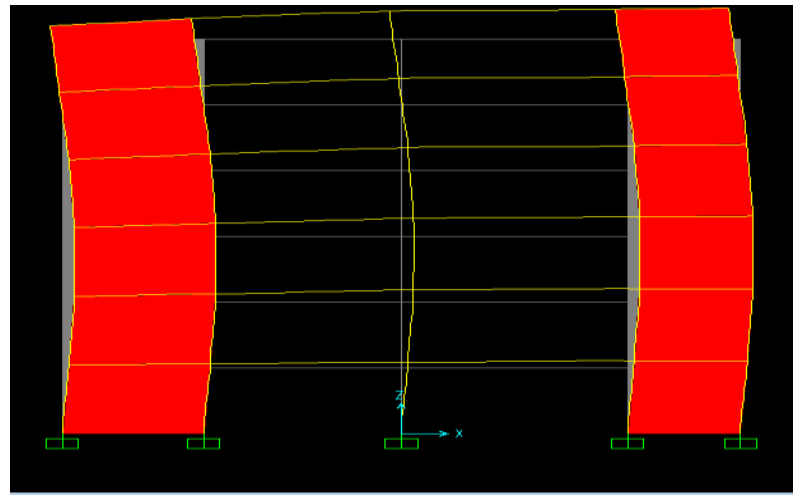

Fig.9. Modal mass representation of RAC

The modal mass for give mode $=6$ has a unique value for NAC building structure of $41.33 \mathrm{sec}$ and RAC building structure of $45.77 \mathrm{sec}$ with irrespective of scaling factor

\section{Relative virtual work/volume of framed building}

Fig.10. and fig.11 represent the relative virtual work/ volume of structure

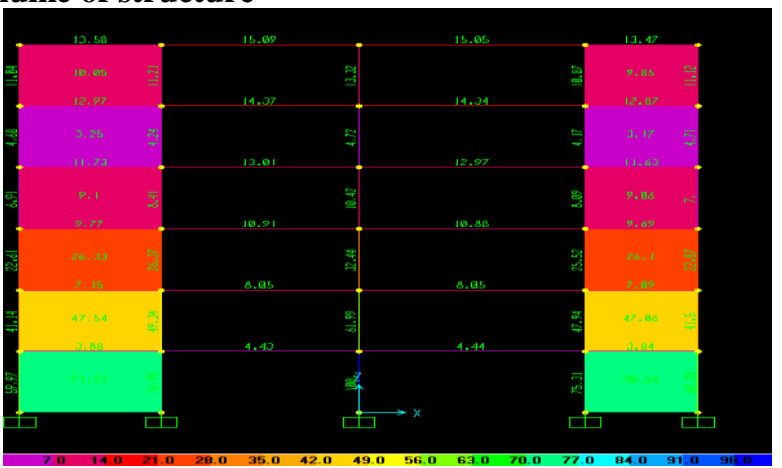

Fig.10. relative virtual work/ volume of NAC building.

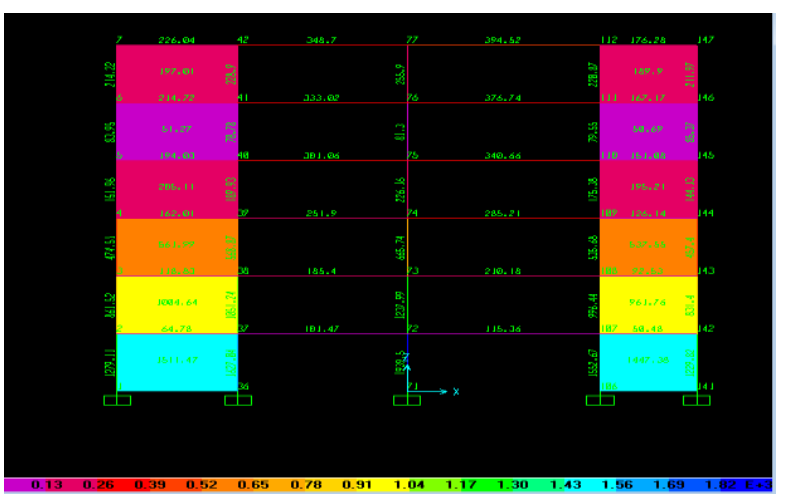

Fig11. relative virtual work / volume of RAC building.
From the fig.11 and fig12 shows that the relative displacement of other level from one level above of RAC building increases when compared to NAC building.

\section{Shear stress of framed building}

According, IS 13920:1993 if the factored shear stress in the wall exceed $0.25 \sqrt{ }$ fck , reinforcement shall be provided in curtains, each having bars running in the longitudinal and transverse direction in the plane of the wall. [22]-[28]

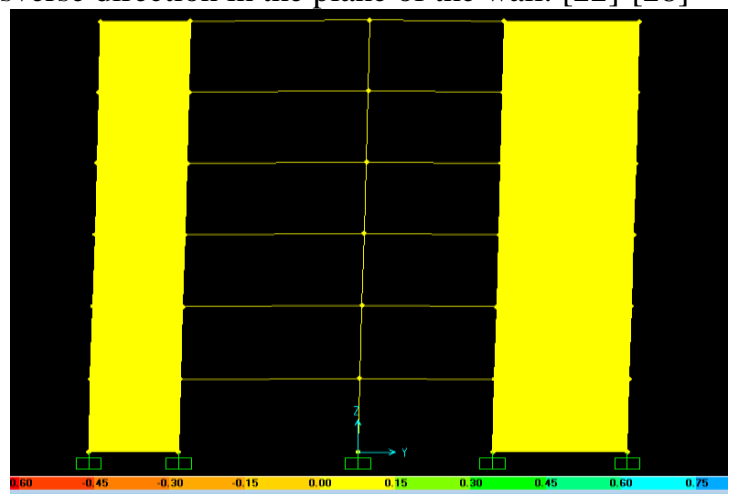

Fig.11. shear stress of NAC framed building

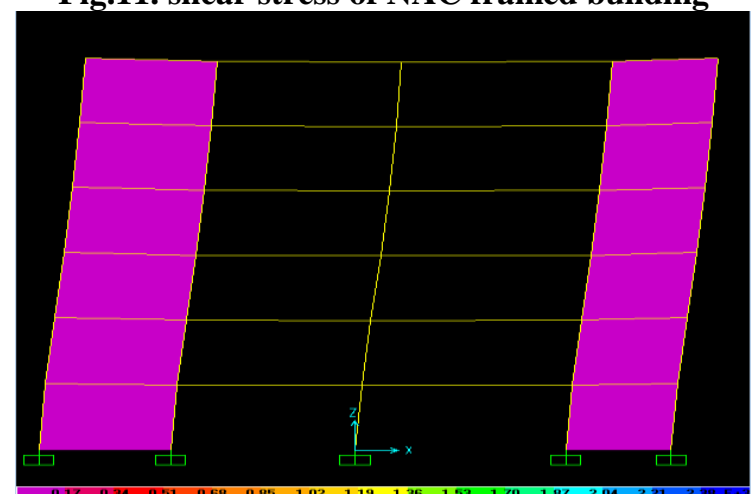

Fig.12 shear stress of RAC framed building.

Fig.11. and fig. 12 represent the shear stress of RAC and NAC of framed building. From these two figures its noted the two structure is within the factored shear stress but the range of shear stress of RAC framed building is higher than the NAC framed building.[29]-[34]

\section{CONCLUSION}

Based on the above result from the analysis of RAC and NAC building models, the following conclusions are made,

$>$ The analytical research has found the RAC and NAC building structure shown insignificant strength degradation and reasonable stability of stiffness.

$>$ Increased value of physical properties in RAC is due to attached mortar and cement paste in the RAC.

$>$ The compressive strength of RAC is relatively lower up to $10 \%$ of the NAC

$>$ The deformed shape of RAC and NAC at mode $=6$ it is seen that the time period taken by RAC is much higher than NAC structure.

\section{REFERENCES}

1. Iyappan L., Dayakar P., Identification of landslide prone zone for coonoortalukusing spatial technology, International Journal of Applied Engineering Research,V-9,I-22,PP-5724-5732,Y-2014.

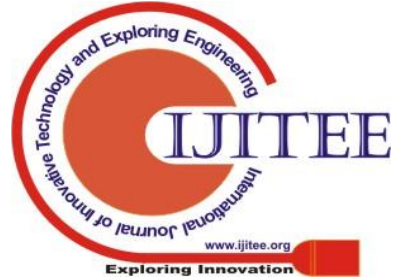

Blue Eyes Intelligence Engineering 
2. Kumar J., Sathish Kumar K., Dayakar P.,Effect of microsilica on high strength concrete, International Journal of Applied Engineering Research,V-9,I-22,PP-5427-5432,Y-2014

3. Dayakar P., Vijay Ruthrapathi G., Prakesh J., Management of bio-medical waste, International Journal of Applied Engineering Research,V-9,I-22,PP-5518-5526,Y-2014.

4. Swaminathan N., Dayakar P., Resource optimization in construction project, International Journal of Applied Engineering Research,V-9,I-22,PP-5546-5551,Y-2014

5. Venkat Raman K., Dayakar P., Raju K.V.B.,An experimental study on effect of cone diameters in penetration test on sandy soil, International Journal of Civil Engineering and Technology,V-8,I-8,PP-1581-1588,Y-2017.

6. Saritha B., Chockalingam M.P.,Photodradation of malachite green DYE using TIO2/activated carbon composite,International Journal of Civil Engineering and Technology,V-8,I-8,PP-156-163,Y-2017

7. Shendge R.B., Chockalingam M.P., Saritha B., Ambica A.,Swat modelling for sediment yield: A case study of Ujjani reservoir in Maharashtra, India,International Journal of Civil Engineering and Technology,V-9,I-1,PP-245-252,Y-2018

8. Chockalingam M.P., Balamurgan V.,Modernisation of an existing urban road-sector in Chennai, a case study report,International Journal of Civil Engineering and Technology,V-8,I-8,PP-1457-1467,Y-2017

9. Saritha B., Chockalingam M.P.,Adsorption study on removal of basic dye by modified coconut shell adsorbent, International Journal of Civil Engineering and Technology,V-8,I-8,PP-1370-1374,Y-2017

10. Saritha B., Chockalingam M.P.,Adsorptive removal of heavy metal chromium from aqueous medium using modified natural adsorbent,International Journal of Civil Engineering and Technology,V-8,I-8,PP-1382-1387,Y-2017

11. Chockalingam M.P., Palanivelraja S.,Retrospective analysis of a theoretical model used for forecasting future air quality near the north Chennai thermal power plant,International Journal of Civil Engineering and Technology,V-8,I-8,PP-1457-1467,Y-2017

12. Saritha B., Chockalingam M.P.,Photodegradation of methylene blue dye in aqueous medium by $\mathrm{Fe}-\mathrm{AC} / \mathrm{TiO} 2$ Composite,Nature Environment and Pollution Technology,V-17,I-4,PP-1259-1265,Y-2018

13. Shendge R.B., Chockalingam M.P., Kaviya B., Ambica A.,Estimates of potential evapotranspiration rates by three methods in upper Bhima Basin, In Maharashtra, India,International Journal of Civil Engineering and Technology,V-9,I-2,PP-475-480,Y-2018

14. Shendge R.B., Chockalingam M.P.,The soil and water assessment tool for Ujjani Reservoir,International Journal of Mechanical Engineering and Technology,V-9,I-2,PP-354-359,Y-2018

15. Shendge R.B., Chockalingam M.P.,A review on soil and water assessment tool,International Journal of Mechanical Engineering and Technology,V-9,I-2,PP-347-353,Y-2018

16. Sachithanandam P., Meikandaan T.P., Srividya T.,Steel framed multi storey residential building analysis and design,International Journal of Applied Engineering Research,V-9,I-22,PP-5527-5529,Y-2014

17. Meikandaan T.P., Ramachandra Murthy A.,Study of damaged RC beams repaired by bonding of CFRP laminates,International Journal of Civil Engineering and Technology,V-8,I-2,PP-470-486,Y-2017

18. Meikandaan T.P., Ramachandra Murthy A.,Retrofittng of reinforced concrete beams using GFRP overlays,International Journal of Civil Engineering and Technology,V-8,I-2,PP-423-439,Y-2017

19. Meikandaan T.P., Ramachandra Murthy A.,Flexural behaviour of RC beam wrapped with GFRP sheets,International Journal of Civil Engineering and Technology,V-8,I-2,PP-452-469,Y-2017

20. Meikandaan T.P., Murthy A.R.,Experimental study on strengthening of rc beams using glass Fiber,International Journal of Civil Engineering and Technology,V-9,I-11,PP-959-965,Y-2018

21. Meikandaan T.P., Hemapriya M.,Use of glass FRP sheets as external flexural reinforcement in RCC Beam,International Journal of Civil Engineering and Technology,V-8,I-8,PP-1485-1501,Y-2017

22. Saraswathy R., Saritha B.,Planning of integrated satellite township at Thirumazhisai,International Journal of Applied Engineering Research,V-9,I-22,PP-5558-5560,Y-2014

23. Saritha B., Ilayaraja K., Eqyaabal Z.,Geo textiles and geo synthetics for soil reinforcement,International Journal of Applied Engineering Research,V-9,I-22,PP-5533-5536,Y-2014

24. Ambica A., Saritha B., Changring G., Singh N B., Rajen M., Salman Md.,Analysis of groundwater quality in and around Tambaram taluk, Kancheepuram district,International Journal of Civil Engineering and Technology,V-8,I-8,PP-1362-1369,Y-2017
25. Arunya A., Sarayu K., Ramachandra Murthy A., Iyer N.R.,Enhancement of durability properties of bioconcrete incorporated with nano silica,International Journal of Civil Engineering and Technology,V-8,I-8,PP-1388-1394,Y-2017

26. Ilayaraja K., Krishnamurthy R.R., Jayaprakash M., Velmurugan P.M., Muthuraj S.,Characterization of the 26 December 2004 tsunami deposits in Andaman Islands (Bay of Bengal, India),Environmental Earth Sciences,V-66,I-8,PP-2459-2476,Y-2012

27. Ilayaraja K.,Morphometric parameters of micro watershed in Paravanar sub-basin, Cuddalore District,International Journal of Civil Engineering and Technology,V-8,I-8,PP-1444-1449,Y-2017

28. Ilayaraja K., Singh R.K., Rana N., Chauhan R., Sutradhar N.,Site suitability assessment for residential areas in south Chennai region using remote sensing and GIS techniques, International Journal of Civil Engineering and Technology,V-8,I-8,PP-1468-1475,Y-2017

29. Ilayaraja K., Reza W., Kumar V., Paul S., Chowdhary R.,Estimation of land surface temperature of Chennai metropolitan area using Landsat images,International Journal of Civil Engineering and Technology,V-8,I-8,PP-1450-1456,Y-2017

30. Chitra R.,Experimental study on beam using steel fiber and latex,International Journal of Civil Engineering and Technology,V-8,I-8,PP-1395-1403,Y-2017

31. Chitra R.,Analysis of traffic and management at Kovilambakkam intersection,International Journal of Civil Engineering and Technology,V-8,I-8,PP-1433-1443,Y-2017

32. Aswathy M.,Experimental study on light weight foamed concrete,International Journal of Civil Engineering and Technology,V-8,I-8,PP-1404-1412,Y-2017

33. Aswathy M.,Wastewater treatment using constructed wetland with water lettuce (Eichornia Crasipies),International Journal of Civil Engineering and Technology,V-8,I-8,PP-1413-1421,Y-2017

34. Kiruthiga K., Anandh K.S., Gunasekaran K, Assessment of influencing factors on improving effectiveness and productivity of construction engineers, 2015, International Journal of Applied Engineering Research, V - 10,I -17,p -13849-13854.

\section{AUTHORS PROFILE}

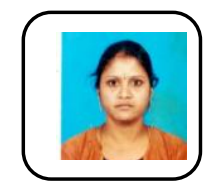

R. Chitra, Asistant Professor, Department Of Civil Engineering,,Bharath Institution of Higher Education And Research,TamilNadu, India

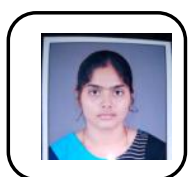

Shruthi M V, Asistant Professor,,Department Of Civil Engineering,,Bharath Institution Of Higher Education And Research,TamilNadu, India

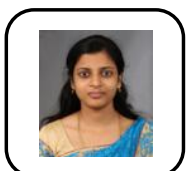

Rinu Isah, Asistant Professor,,Department Of Civil Engineering,,Bharath Institution Of Higher Education And Research,TamilNadu, India 